\title{
Metabolic engimeering of microorganisms for biofuels production: from bugs to synthetic biology to fuels
}

\author{
Sumg Kuk Lea, Howard Chou, Tünothy S Ham, Taek Soon Lec, and Jay D Keasling
}

ABSTRACT

The ability to generate microorganisms that can produce biofuels similar to petroleum-based transportation fuels would allow the use of existing engines and infrastructure and would save an enomous amount of tapital requited for replacing the cutrent infristructure to accommodate biofuels that have properties significantly different from petroleurn-based fuels. Several groups have demonstrated the feasibility of manipulating microbes to produce molecules similar to petroleum-derived products, albeit at relatively low productivity (e.g. maximum butanol production is around $20 \mathrm{~g} / \mathrm{L}$ ). For cost-effective production of biofuels, the fuel-producing hosts and pathways nust be engineered and optirnized. Advances in metabolic engineering and synthetic biology will provide new tools for metabolic engineers to better understand how to rewire the cell in order to create the desired phenotypes for the production of economically viable biofuels.

\section{INTRODUCTION}

A ltemative transportation fuels are in high demand owing to concoms about elimate change, the global petroleum supply, and energy security [ 1,2]. Currently, the most widely used biofuels are ethanol generated from starch (com) or sugar cane and bjodiesel produced from vegetable oil or animal fats [3']. However, ethanol is not an ideal fuel molecule in that it is not compatible with the existing fuel inftastructure for distribution and storage owing to its corrosivity and high hygroscopicity [1,4"u. Also, it contains only about $70 \%$ of the energy content of gasoline. Biodiesel has similar problens (URL: http: $/ /$ WWw.bdpedia.com/biodiesel/all/all.html): it canthoc be transported in pipelines because its cloud and pour points are higher than those for petroleum diessel (petrodiesel), and its energy content is approxinately $11 \%$ lower then that of petrodiesel. Furthermore, both ethanol and bio-diesel are currently produced from limited agricultural resources, even though there is a large, untapped resource of plant biomass (lignocellulose) that could be utilized as a renewable source of carbon-neutral, liquid fuels [ 5 ].

Microbial production of transportation fuels from renew-able lignocellulose has several advantages. First, the production is not reliant on agricultural resources commonly used for food, such as corn, sugar cante, soybean, and palm oil. Second, lignoceilulose is the most abundant biopolymer on earth. Third, new biosynthetic pathways can be engineered to produce fossil-fuel replacements, including shortchain, branched-chain, and cyclic alcohols, alkanes, alketes, esters and aromatics. The development of cost-effective and energy-efficient processes to convert lignocellulose into fuels is hampered by significant roadblocks, including the lack of genetic engineering tools for native prodocer organisms (non-model organ-isms), and difficulties in optimizing metabolic pathways and balancing the redox state in the engineered mierobes [ 6]. Futthortmote, production potentials are limited by the low activity of pathway enzymes and the inhibitory effect of fuels and byproducts from the upstream biomass processing steps on microorganisms responsible for producing fuels. Recent advances in synthetic biology and metabolic engineering will make it possible to overcome these hurdles and engineer microorganisms for the costeffective production of biofuels from cellulosic biomass. In this review, wo examine the range of choices available potential biofuel candidates and production hosts, review the recent methods used to produce biofuels, and discuss how tools from the fields of metabolic engineering and synthetic biology can be applisd to produce transportation fuels using gentetically engineered micro-organisms.

\section{Liguid fuels and alternative biofuel molecules}

An understanding of what makes a good fuel is important in order to retool microorganisms to produce more useful altemative biofuels. The best fuel targets for the near term will be molocules that are already found in or similar to components of fossil-based fuel in order to be compatible with existing engines (spark ignition engime for gasoline, compression ignition engine for diesel fuel, and gas turbine for jet fuel). There are several relevant factors to consider when designing biofitel candidates (Table 1). Energy contents, the combustion quality described by octane or cetane mumber, volatility, freezing point, 
odor, and toxicity are important factors to consider. In the following section, we will consider several biofuel candidates and their properties.

Tabie I

Types of liquid fuels.

\begin{tabular}{|c|c|c|c|}
\hline Fuel type & Major components & Inporteul pnoperty & Biasynthetic altornatives \\
\hline Oasoline & $\begin{array}{l}C_{1}-C_{12} \text { hydracaitrons } \\
\text { Lintedr, branched, cyclic, trontatics } \\
\text { Anti-knock addilives }\end{array}$ & 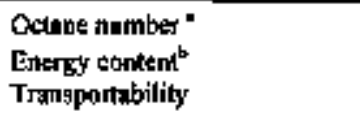 & 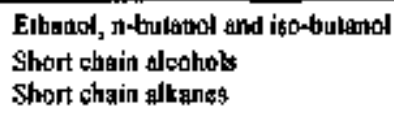 \\
\hline Diessel & $\begin{array}{l}C_{2}-C_{21} \text { (average } C_{6} \text { ) } \\
\text { Linear, branched, cyelic, tromatic } \\
\text { Anli-ficese addilives }\end{array}$ & $\begin{array}{l}\text { Colane number } \\
\text { Low freezing temperalure } \\
\text { Low vapos pressoups }\end{array}$ & $\begin{array}{l}\text { Biodiesel (FAMEs) } \\
\text { Fatty akcohols, alkanes } \\
\text { Lipfar or cyclic isppranoids }\end{array}$ \\
\hline Jet fiel & $\begin{array}{l}\mathrm{C}_{-}-\mathrm{C}_{16} \text {, hydrocarbons } \\
\text { Linear, banphed, cyclic, arconatic } \\
\text { Anti-fieres additives }\end{array}$ & $\begin{array}{l}\text { Yery low freeding temperature } \\
\text { Net heat of combustion } \\
\text { Density }\end{array}$ & $\begin{array}{l}\text { Alkauos } \\
\text { Biodiess } \\
\text { Linear or eyclic isaprenoids }\end{array}$ \\
\hline
\end{tabular}

a A measurentent of its resistance to knocking. Knocking occurs when the facldair mixhure spontaneously igniles before it raches the optimum pressure and tertaperstute for spatk ignition.

b The arsount of energy prodected during combuation, The mumber of $\mathrm{C}-\mathrm{H}$ and $\mathrm{C}-\mathrm{C}$ bonds in a motecule is a good indication of bow much energy a patidcular fuel will produce.

c. A measurement of the combustion quatity of diegel fued during compression ignilion. A storter ignition delay, the lime period between the start of imjection and starn of combustion of the fuel is prefented, and the ignition delay is indexed by the cetane number.

\section{Gasoline and ifs altematives}

Gasoline is a complex mixture of hydrocarbons including linear, branched, and cyclic alkanes $(40-60 \%)$, aromatics (20-40\%), and oxygenates [ 7]. The carbon number of hydrocarbons in gasoline varies from 4 to 12. Ethanol, the most popular additive to gasolitn, has an octane number of 129, but its energy content per gallon is about $70 \%$ of that of gasoline. Ethanol also has problems as a fuel owing to high miscibility with water, which makes it difficult to distill from the fermentation broth and to transport through existing pipelines. Recently, n-butand has received more attention as an alternative gasoline additjve. Butanol has two more carbons than ethanol, which results in an energy content of about $40 \%$ higher than that of ethanol. The oclane number of butanol is 96 [ 8], which is somewhat lower than that of ethanol but is still comparable to that of gasoline (9]-99). Unlike ethenol, butanol is less soluble in water than ethanol. It can also be used not only as an additive to gasoline but also as a fuel by itself in conventional engines (URL: http://ww w.butarol.com).

In general, the octane number increases when the molecule has methyl branching and double bonds. Btanched $\mathrm{C}_{4}$ and $\mathrm{C}_{5}$ alcohols are also considered potential gasoline additives. Among them, isobutanol (2-methyl-1-propa-nol) has very similar properties to n-butanol with a higher octane number, and is currently under investigation as a new biofuel target (URL: http:/Www.gevo.com). Other short chain alcohols, such as isopentanol (3-methyl-1-butanol or isoanyl alcohol) and isopentenol (3-methyl-3buten- 1 -ol or 3-methyl-2-buten-1-ol) are also attractive gasoline fuel additives. Their octane numbers range slightly above 90 , and they have higher energy contents than butanol. These alcohols can be produced from the isoprenoid biosynthetic pathway [9] or by transformation of amino acids as reported recently [4"]. Branched, short-chain alkanes such as iscoctane are a good gasoline replacement, but the biological production of these molectles would require significant changes to existing metabolic pathways and may take significant effort to achieve.

\section{Dhesel and its alternatives}

Diesel fuel is also a complex mixture of hydrocarbons including linear, branched, and cyclic alkanes (75\%) and aromatics (25\%). The carbon number of bydrocarbons in petrodiesel varies from 9 to 23, with an average of 16 (Table 1). Biodiesel is genetally composed of fatty acid methyl esters (FAMEs), and is mostly derived from vegetable oil or animal fat. The fatty acids in FAMEs generally have a chain 

$\mid$

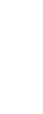

. 
length from 12 to 22 , containing zero to two touble bonds. Biodiassol has a comparable cetane rating and energy content to petrodiesel and additional advantages, such as higher lubricity and less emission of pollutants. Another source for biodiesel would be isoprenoids, which are naturally occurring branched ot cyclic hydrocarbons mostly synthesized in plants. They usually have methyl branches, double bonds, and ring structures, which improve the fluidity at lower tempetatures but lower cetane ratings. Therefore, linear or cyclic monoterpenes $\left(\mathrm{C}_{10}\right)$ or sesquiterpenes $\left(\mathrm{C}_{15}\right)$ are potential targets for biodiesel fuel, especially with complete or partial reduction of double bonds, which would improve the cetane rating.

\section{Biojetfuels}

Jet fuels (Jet A, Jet A-I, JP-8, and JP-5) are also a very complex mixture of hydrocarbons with a carbon number distribution of 8-16 and about $25 \%$ (v/v) limit of aromatics ( Table 1). Jet fuel is very similar to kerosene or diesel fuel, but requires a lower freezing point since it is used under harsh conditions such as extreme cold (URL: hup:/www.boeing.com/oommercial/environ-ment'pd0'alt_fuels.pdf). Linear or branched hydrocarbons with medium carbon chain length produced from the fatty acid or isoprenoid biosynthetic pathways are primary targets for biojetfuels. Recently, the use of isoprenoids as jet fuel has been investigated, as thoy have low freezing points potentlally owing to their branching and cyclic structure (URL:http//business.timesonline,co.uk/tol/business/industry_sectors/natural

resources/article1 $844558 . e c e)$.

\section{Production host}

To convert lignocellulosic biomass into economically viable bioftuels [ \$], the production hosts must natively have or be endowed with several characteristics ( Figure 1). The user-friendly hosts (Escherichia colt and Saccharomyces cerevisiae) that bave well-character-ized genetics and the genetic tools [ 6,10] for manipulating them are good starting points for development as production platforms. Because these host organisms are also facultative anaerobes with fast growth rates, large-scale production processes can be relatively simple and economically viable [ 1]-13]. The successful use of $\mathbf{E}$. coli or $\$$. cerevisias to produce altornative biofuels will require a better understanding of their physiology under a variety of conditions and subsequent strain improvements [ 10]. Continuous advances in 'omics' techmologies, computational systems biology, and synthetic biology make it possible to better understand and engineer fuel production hosts with desized phenotypes $\{6,14\}$.

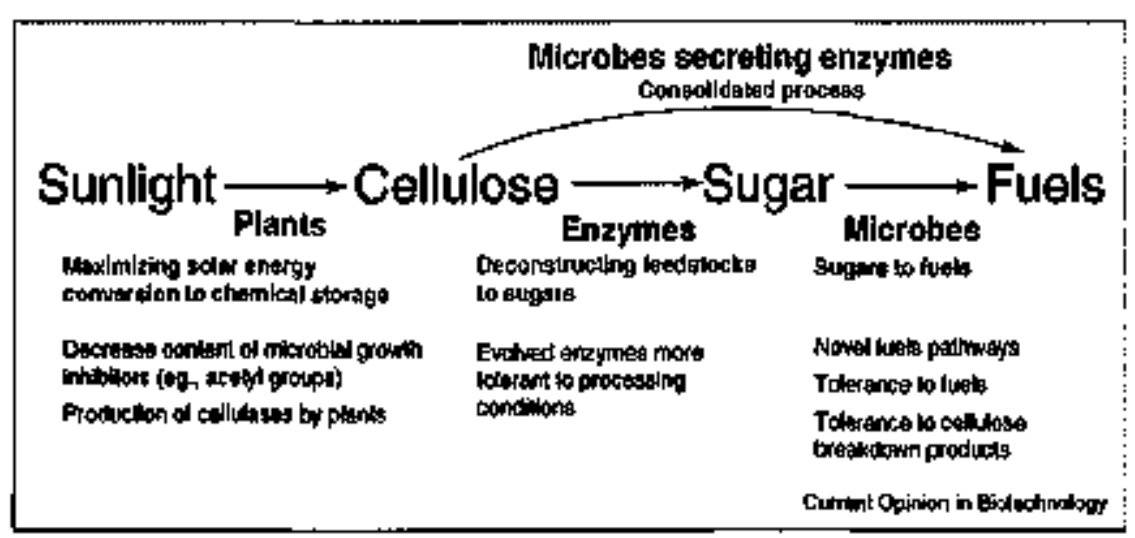

Figute 1

Route from sunfight to fuek. Conversion of biumess lo fuels will inyolye the development of dedicated enercy piants that maximira Bolar energy conwersion to chemical storoge und minimize the use of water ind ferillizer, enzymes that depolymerizz cellolost and

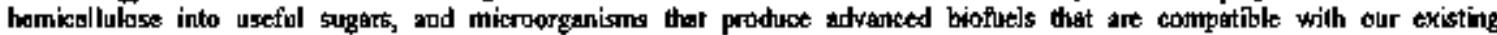
Iransportation infiastruchure. To achieve connamically viable biofuet production, all aspects of these processegs musl be optimized. In particular, production hosts must natively have ot be endowed with several important characterislics: extension of the substrate ranges eliminaiton of cellubse hydrolysates and biofuel producl toxicity, alud improvement of global regulatory funclions. One method that hus been proposed to reduce fuel production cost is to perform cellulose hydrolysis and fermentalion in one step, called consolidated bioprocessing (CBP); this a|ternative approach avoids costs associaterd with cellelase producelon [ 14].

Metabolic engibeering of fuels synthesis pathways

The synthesis pathways of some potential biofuels were recently expressed in model organisms (Table 2). For example, the genes involved in the syuthesis of isopropanol $[16,17]$ and butanol [ 18] from 
Clostriduim were recently expressed in $\mathbf{E}$. coli. Aside from producing ethanol during fermentation, $\mathbf{S}$. cerevisiae is also known to produce hights alcohols and esters from amino acids [ 19- 21]. Recont]y, a similar pathway for higher akohol production was expressed in E. coli to yield six different straight and branched-chain alcohols, and the same group has demonstrated production of $1.28 \mathrm{~g} / \mathrm{L}$ of isopentanol by increasing the flux through the desired pathway [ 22]. Other natural pathways of interest include those for producing fatty acids in onder to make biodiesel (fatty acid methyl/ethyl esters) [ 23] and those for producing alkanes [ 24]. While biodiesel production from microbial organisms has focused on the fatty acid biosynthesis pathways of $\mathbf{E}$. coli and $\mathbf{S}$. cerevisiae, there are efforts to expand production to explore the fatty acid biosyothesis pathway of other organisms, such as cyanobacteria and algae [ 25]. Looking beyond natural pathways, hybrid processes that combime both biological and chemical production steps can also lead to now chemicals that could serve as biofuels [27'1].

Table 2

Examples of difterent metabolic eugineering stralegies for increasing yields of varions biofuels.

\begin{tabular}{|c|c|c|c|}
\hline Biofuel & Stratery & Yiela $\sigma^{2}$ & Reference \\
\hline \multirow[t]{4}{*}{ E'tanot } & $\begin{array}{l}\text { Engingering of phesphokevolase paltway to increase the availability of } \mathrm{NAD}^{+} \text {during xyloge } \\
\text { inctabolism in } \mathbf{S} \text {. Cerovisjoc }\end{array}$ & 0.42 & [29] \\
\hline & 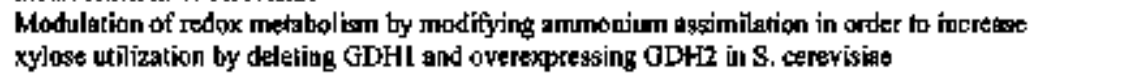 & $0.3 \mathrm{~A}$ & [30] \\
\hline & 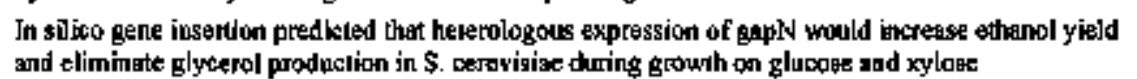 & 0.36 & {$\left[4 B^{\prime}\right]$} \\
\hline & 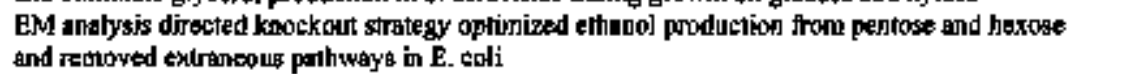 & 0.36 & {$[42]$} \\
\hline \multirow[t]{2}{*}{ Bubanol } & 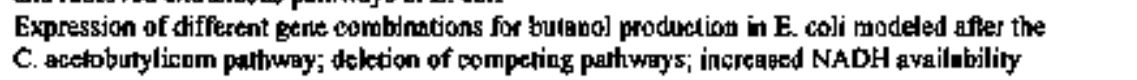 & .0056 & [ 18$]$ \\
\hline & 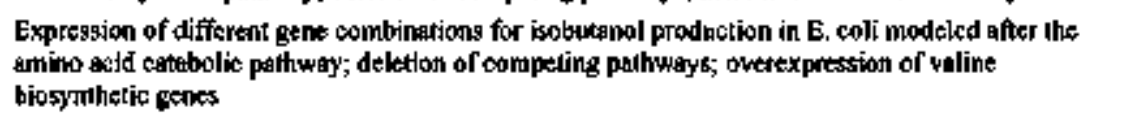 & 0.35 & {$[4 "]$} \\
\hline Pentenol & 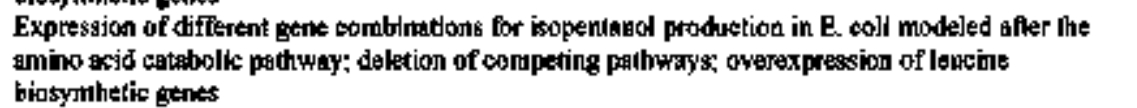 & 0.11 & [ 22] \\
\hline Propanol & $\begin{array}{l}\text { Expression of differenl gente comblntations for propasol production in E. coll modeled after } \\
\text { the C. bejierinckii patbway }\end{array}$ & 0.14 & [17] \\
\hline
\end{tabular}

- Reporterd yiela [g biofixl/[ carbon gowwec].

Constructing biofuel synthesis pathways is only the first hurdle to making biofuels economically viable. The expectations on yield and constraints on cost place many challenges on biofue] production [1,3 28-30]. Some of the obstacles to achieving high yields are a result of the interdependence of metabolic newworks, which are strongly influenced by the global levels of a handful of metabolites: ATP/ADP, $\mathrm{NAD}^{+} / \mathrm{NADH}, \mathrm{NADP}^{+} / \mathrm{NADPH}$, and acyl-CoAs. These central metabolites play an important role in regulating multiple pathways in the cell, because the cell uses the relative ratios of these motrabolites to regulate a pathway's activity and ultimately the physiology of the cell. For example, the redox state of a cell is essentially determined by the relative ratio of NAD ${ }^{+}$to NADH. The incorporation of new pathways for biofuel synthesis can destabilize the balatic of these important metabolites, leading to the production of undesirable byproducts and a decrease in yield. Furthermoro, the new metabolic pathway requires amino acids, redox cofactors, and energy for synthesis and function of its enzymes, which places a metabolic burden on the cell that must be minimized to maximize production of the final product.

One way to predict the impact of a now metabolic pathway on growth and product formation is through the use of metabolic models. Over the years, biochemical models of $\mathbf{E}$. coli [ 31] and S. cerevisiae [ 32] metabolism have become more sophisticated. As a result, genome-scale models are playing a larger role in directing metabolic engineering efforts with more rational and systematic approaches [ 33]. Many of the in silico models are stoichiometric models with large solution spaces, because the equations describing the models ate usually underdetermined. However, the proper use of constraints has achieved some success in producing models that can link genotype to phenotype [ 34]. The stoichiometic models can also be described by a set of determined equations using metabolic flux analysis (MFA), where the exchange 
$\mid$ 
fluxes are measured experimentally. MFA has been useful in studying the native metabolism of E. co]i under different growth conditions [ 35] and during recombinant protein production [ 36]. Many important Insights into microbial metabolism have been schieved using metabolic models, such as predieting the phenotypic space of adaptive evolution in E. coli during growth on different carbon sources [ 37] and the topological organization of the high-flux reactions in E. coli's metabolic network [38']. It was demonstrateo that $\mathrm{E}$. coll adapts to various growth contitions by reorganizing the rates through a set of high-flux reactions. Biofusol production tfforts tan benefit from genome-scale models, which provide a systematic framework for optimizing flux through the desired pathways, while balancing important cofactor and energy metabolites.

Recently, in silico models have played an important role in engineering microorganisms to utijize new substrates to produce biofuels more efficiently. The ability to use a wider array of the biomass feedstocks would help to decrease cost by reducing the number of upstream processing steps and by turning more of the biomass into biofuel. For example, $S$. cerevisiae has been engineered with the genes encoding xylose reductase (Xyllp) and xylitol dehydrogenase (Xyl2p) from Pichia stipitis to enable it to utilize xylose, the second most abundant earbohydrate in nature, as a carbon source for ethanol production [ 39]. However, simpiy overexpressing the genes lad to low growth and formentation rates due to redox imbalance. Xylose reductase from P. stipitis has a higher affinity for NADPH than NADH, while xylitol dehydrogenase uses only NAD*. Overexpression of both genes leads to an accumulation of NADH and a shortage of NADPH, Metabolic models suggested that the cofactors could be balanced by deleting NADP ${ }^{+}$dependent glutamate dehydrogenase (GDH1) and overexpressing NAD -dependent GDH2 to increase the specific activity of Xyllp for NADH. This strategy led to an increase in ethanol production and a reduction in byproduct syn-thes is [ 40 ]. Interestingly, overexpression of the $P$. stipitis xylose reductase also increased tolerance to lignocellu]osic hydrolysate [ 41].

Elementary mode (EM) analysis was also used to engineer a strain of $\mathbf{E}$. coli that can șimultaneously utilizs both glucose and xylose as carbon sources to produce ethano] [42]. EM analysis was used to identify a minimum set of metabolic pathways that would support growth and ethanol production on hexoses and pentoses, by removing reactions that supported maximum ethanol and high bionass yields but whose removal led to the lowest number of remaining EMs. Using this strategy, the bur-den from extraneous pathways was reduced in the knockout mutants, so more cellular resources could be directed toward biofuel synthesis. In another example of metabolic engineering, byproduct formation was minimized in $\mathrm{E}$. coli during fermentation by disrupting the tricarboxylic acid cycle in order to raduce oxygen demand for NADH oxidation and eliminating pathways for NADH oxidation other than the electron transport system [ 43]. Other methode for cofactor balancing include overexpressing proteing to increase NADH [ 44] or NADPH [ 45] availability, interconverting NADH and NADPH [ 46], and changing the coenzyme specificity of specific proteins [ 47]. In silico genome-scale models have also been oxtended beyond gene deletion or overexpression strategies to include gene insertion strategies for redox balancing. The in silico gene insertion strategy was used to improve ethanol production and decrease the production of the byproducts glycerol and xylitol. The result was a $58 \%$ reduction in glycerol, a $33 \%$ reduction in xytitol, and a $24 \%$ increase in ethanol production when glyceralde-hyde-3-phosphate dehydrogenase was introduced into S. cerevisige [48']. These techniques demonstrate the importance of monitoring and balaneing the levels of various important metabolites in order to achieve optimal product titers. Therefore, metabolic engineering will play an important role in enginesisag efficient microbjal pathways for the production of economically sustinable biofuels.

The role of syutbetic biolagy In metabolic engineening for biofuels production

Synthetic biology is an emerging field that aims to bring such engineering principles as modularization and componentization to the manipulation of genetic circuity in microorganisms, so that engineering an organism for fuel production is as easy as assembling a computer [49"']. Unlike bigh-value, rare products like pharmaceuticals or enzymes, fuels are commodity materials that are extremely cost sensitive. Biofuels cen only be competitive when the production costs are less than or equivalent to drilling and refining petroleutm, and thus the viability of biofuels depends absolutely on reducing production costs. In order to achieve this goal, any extraneous cellular processes that reduce production must be systematically controlled. To do this, technologies that enable rapid prototyping, testing, and optimization of pathways and the host organisms are crucial.

Some of the key thrusts of synthotic biology are reducing the time required to make gentetic 
constructs and increasing their predictability and reliability. The construction of many pathway variations and permutations [ 50] can be more efficiently handled by better assernbly techniques rather than through synthesis of each permutation. For example, techniques such as ligatjon-free BioBricks [ \$3] are enabling rapid construction of operons and pathways from existing DNA fragnents or genes. The BioBrick method, in particular, has the interesting property that the end result of assembly hes the sarme restriction sites as at the start of the assembly-that is, oach stage of assembly uses the enzymes and processes identical to the previous stage. This repetitive and cyclic nature of the method is ripe for automation, facilitating the creation of large permutation libraries quickly. Another thrust of synthetic biology is the creation of reusable parts that have useful and predictable behavior. The development of a diverse amay of regulatable expression systems [ 54,55] that can be used to fine-tune expression is very useful in engineering metabolic pathways. Also, switches that sense and respond to environmentel changes [ 56,57] and can subsequently initiate down-stream regulation have exciting opportunities for biofuels production. For example, it may be possible to design bacteria that switch from a cellulose digestion mode to fuel production mode by sensing the surrounding environment. Such advanced signal processes and decision-making capabilities have already been demonstrated in a remarkable way - for example, the tumnor sensing bacteria that can sense and selectively invade anaerobic environtrnents in a tumor [58] - and adopting these technologies for metabolic engineering may have fruitful results. Furthenmore, the development of intra-cellular and intercellular signal processing abilities in microbes [ 59] as well as fine control over pathway expression are opening up the potential for coordinated gene expression and regulation for optimum production.

One of the more difficult challenges of metabolic engineering is the integration of severat parts or enzymatic pathway fragments into a functioning device ('functional composition' in synthetic biology parlance). For example, Ro et al. [ 60] were able to take the already optimized mevalonate pathway [ 61] and extend it to produce artemistnic acid. As the number of biologically produced molecules increases, the need to reuse and mix enzymatic pathways or subpathways will increase as wel] [ 62]. Creation of modular subpathways that can be easily interconnected is an area of active research with much potential. To achieve this goal, a strong ftamework for characterization and standardization is being sought. Recent efforts in standardizing measurements [63'] are encouraging, but further refinements of the methods by which these parts are lested and characterized as well as industry-wide agreement on those methods is necessary. Still, the development of syththetic gene regulation networks from scratch [ 64] and methods for analyzing them in silico [ 65] is extremely encouraging. Looking forward, the development of a 'chassis' organism for synthetic bjology is a difficult and ongoing endeavor. For molabolic engineers, transferring a working pathway from one organism to another is a difficult but sometimes necessary maneuver for greater product ytelds. Synthetic biologists art looking to either modify existing organisms or create from scratch microorganisms with minimal genomes and therefore with a minimal set of metabolic pathways [ 66]. The hope is that such an organism will lead to more predictable behaviors when a foreign gene or a pathway is introduced, as any potential side pathways are known and/or controllable. In the similar vein, in vivo mutagenesis and screening techniques hold promise in whole gentone engineeríg.

The prospect of assembling new motabolic pathways by simply putting together sub pathways into a welldefined chassis is very exciting. The rapid recent advances in synthetic biology techniques have brought new tools for assembly and control that move the entire field closer to this gool. Many of the techniques in synthetic biology are readily adaptable to metabolic engineering of microorganisms to fuels production, and already strong relationships are being forged between metabolic engineering and synthetic biology' com-munities. Quick adoption of the ever-sxpanding sets of tools in synthetic biology will be enomously beneficial in tackling challenging metabolic engineering projects, such as biofuels production.

\section{CONCLUSION}

Recent increases in energy and fuels costs have resulted in increased attention to finding alternatives to fossil fuels. However, unlike the previous efforts to develop biofuels in the 1970 s and early 1980s, we are armed with better tools to manipulate cellular metabolism in order to produce these fuels. Even more, with the advanced tools of synthetic biology, it is possible to produce biofuel candidates that are not naturally produced, enabling us to use our existing transportation infrastructure rather than replace it in order to use 'rnatural' biofuels like ethanol. In any case, metabolic engineering and synthetic biology will be central actors in the biofuels revolution, and the mblecules and the tectniques covered in this article will surely play important roles in its evolution. 


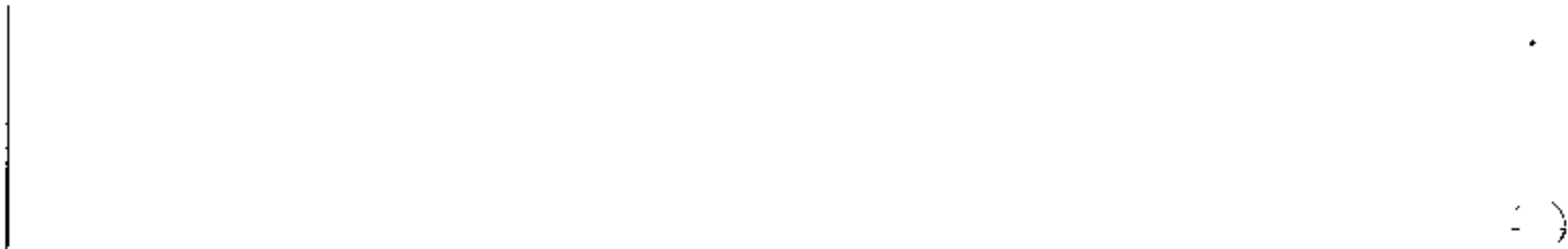

$-\quad$ 


\section{ACKNOWLEDGEMENTS}

This work was funded by the Joint BioEnergy Institute (JBEJ) through a grant from the US Department of Energy and by the Synthetic Biology Engineering Research Center (SynBERC) through a grant from the National Science Foundation. The authors would like to thenk Dr Harry Beller for discussion.

\section{REFERENCES AND RECOMMENDED READING}

1. Stephanopoulos 0 : Challenges in engineering microbes for biofuels production. Scienco 2007, 315:801-804.

2. Kerr RA: Global warning is changing the world. Science 2007, 316:188-190.

3. Fortman IL, Chhabra S, Mukhopadhyay A, Chou H, Lee TS, Steen E, Keasling JD:: Biofuels alternatives to ethanol: pumping the microbial well. Trends Biotechnol 2008, 26:375-331.

4. Atsumi \$, Hanai T, Liao JC: Non-fermentative pathways for 33 synthesis of branched-chain higher alcohols as biofuels. Nature 2008, 451:86-89.

5. Blanch HW, Adams PD, Andrews-Cramer KM, Frommer WB, Simmons BA, Keasling JD: Addressing the need for alternativo transportation fuels: the joint BioEnergy institute. ACs Chem Biot 2008, 3:17-20.

6. Mukhopadhyay A, Redding AM, Rutherford BJ, Keasling JD: Importance of systems biology in engineering microbes for biofuel production. Curr Opin Biotechnol 2008, 19:228-234.

7. Sawyer RF: Trends in auto emissions and gasoline composition. Enviton Health Perspect 1993, 101:5-12.

8. Kuyper M, Hartog MM, Toirkens MJ, Almering MJ, WinkJer AA, van Dijken JP, Pronk JT: Metabolic enginesting of a xylose-isomerase-expressing Saccharomyces cerevisiae strain for rapid anaerobic xylose fermentation. FEMS Yeast Res 2005, 5:399-409.

9. Withers ST, Gottlieb SS, Lieu B, Newman JD, Keasling JD: Ideatification of isopentenol biosynthetic genes from Bacillus subtilis by a screening method based on isoprenoid precursor toxicity. Appl Environ Mierobiol 2007, 73:6277-6283.

10. Fischer CR, Klejn-Marcuschaner D, Stephanopoulos G: Selection and optimization of microbial hosts for biofuels production. Metab Eng 2008, doi:10.1016/j.ymben.2008.06.009.

11. Farmer WR, Liao Je: Improving lycopene production in Escherichia coli by engineering metabolic control. Nat Biotechnol 2000, 18:533-537.

12. Khosla C, Keasling JD: Metabolic engineering for drug discovery and development. Nat Rev Drug Discov 2003, 2:1019-1025.

13. Ingram LO, Aldrich HC, Borges ACC, Causey TB, Martinez A, Morales F, Saleh A, Underwood SA, Yomano LP, York SW et al.: Enteric bacterial catalysts for fuel ethanol production. Biotechnol Prog $1999,15: 855-866$.

14. Lynd LR, van ZyI WH, MeBride JE, Laser M: Consolidated bioptocessing of cellulosic biomass: an update. Cur Opin Biotechnol 2005, 16:577-583.

15. Chen IS, Hiu SF: Acetone butanol isopropanol production by Clostridium-Beijerinckii (Synenym, Clostridium-Butylicum). Biotechnol Lett 1986, 8:371-376.

16. Hanai T, Atsumi S, Liao JC: Enginered synthetic pathway for iscopropanol production in Escherichia coli. Appl Environ Microbiol 2007, 73:7814-7818.

17. Atsumi S, Canna AF, Connora MR, Shena CR, Smitha KM, Brynildsena MP, Choua KJY, Hennai T. Liao JC: Metabolic engineering of Escherichia coli for 1-butanol production. Metab Eng 2008, doi:10.1016/j.ymben.2007.08.003.

18. Schoondermark-Stolk $\$ A$, Jansen M, Veurink JH, Vetkleij AJ, Verrips CT, Euverink GJW, Boonstra J, Dijkhuizen L: Rapid identification of target genes for 3-methyl-1-butanol production in Saccheromyces cerevisiat. Appl Microbiol Biotechnol 2006, 70:237-246.

19. Sentheshanmuganathan S: Mechanism of the formation of higher alcohols fron amino acids by Saccharomyces cerevisiae. Biochem I 1960, 74:568-576.

20. Yoshimoto $\mathrm{H}$, Fukushige $T$, Yonezawa $T$, Sone $\mathrm{H}$ : Genetic and physiological analysis of branchedchain alcohols and isoamyl acetate production in Saccharomyces cerevisiae. Appl Microbiol Biotechnol 2002, 59:501-508. 
\begin{tabular}{|l}
$\mid+1$ \\
$\vdots$
\end{tabular} 
21. Connor MR, Lian JC: Engineering Escherichia coli for the production of 3-methyl-1-butanol. Appl Environ Microbiol 2008, 74:5769-5775.

22. Kalscheuer R, Sto"Iting T, Steinbu"chel A: Microdiesel: Escherichia coli engineered for fuel production, Microbiology 2006, 152:2529-2536.

23. Ladygina N, Dedyukhina EG, Vainshtein MB: A review on microbial synthesis of hydrocarbons. Process Biochem 2006, 41:1001-1014.

24. Chisti Y: Biodiesel from microalgae. Bictechnol Adv 2007, 25:294-306.

25. Roman-Leshkov Y, Barrett CJ, Liu ZY, Dumesic JA: Production of 3 a dimethylfuran for liquid fuels from biomass-derived carbohydrates. Nature 2007, 447:U982-U985.

26. Keasling JD, Chou $\mathrm{H}$ : Metabolic engineering delivers next-generation biofuels. Nal Biotechnol 2008, 26:298-299.

27. Sonderegger M. Schumperti M, Sauer U: Metabolic engineering of a phosphoketolase pathway for pentose catabolism in Sacharomyces cerevisiae. Appl Enviton Microbiol 2014, 70:28922897.

28. Roca $C$, Nielsen $J$, Olsson $L:$ Metabolic engineering of ammonium assimilation in xylose-fermenting Saceharomyees cerevisiae improves thanol production. Appl Enviton Microbiol 2003, 69:47324736.

29. Reed JL, Vo TD, Schilling CH, Palsson BO; An expanded genome-scale model of Escherichia coli K-12 (iJR9O4 GSM/ GPR), Genome Biol 2003, 4:R54.

30. Forster J, Famili 1 , Fu P, Palsson BO, Nielsen J: Genome-scale reconsiruction of the Saccharomyces cerevisiae metabolic network. Genome Res 2003, 13:244-253.

31. Patil KR, Akesson M, Nielsen J: Use of genome-scale microbjal models for metabolic engineering. Curr Opin Biotectinol 2004, 15:64-69.

32. Price ND, Reed $J$, Palsson BO: Genome-scale models of microbtal cells: evaluating the consequences of constraints. Nat Rev Microbiol 2004, 2;886-897.

33. Kayser A, Weber J, Hecht V, Rinas U: Metabolic flux analysis of Escherichia coli in glucose-limited continuous culture. I. Growth-rate dependent metabolic efficiency at steady state. Microbiology 2005, 151:693-706.

34. Ozkan P, Saríyar B, Utkur FO, Akman U. Hortacsu A: Metabolic flux analysis of recombinant protein overproduction in Escherichía coli. Biochem Eng J 2005, 22:167-195.

35. Ibarra RU, Edwards JS, Palsan B0: Escherichia coli K-12 undergoes adaptive evolution to achieve in silico predicted optimal growth. Nature 2002, 420: 186-189.

36. Almaas E, Kovaes B, Vicsek $T$, Olivai ZN, Barabasi AL: Global 3 organization of metabolic fluxes in the bacterium Escherichia coli. Nature 2004, 427:839-843.

37. Chu BCH, Lee H: Genetic improvement of Saccharomyces cerevisiae for xylose fementation. Biotechnol Adv 2007, 25:425-441.

38. Jeffties $\Upsilon W$ : Engineering yeasts for xylose metabolism. Curr Opin Biotechnol 2006, 17:320-326.

39. Almeida JR, Modig T, Ro"der A, Lide'n G, Gorwa-Graustund MF: Pichia stipitis xylose reductase helps detoxifying lignocellulosic hydrolysate by reducing 5-hydroxymethyl-furfural (HMF). Biotechnol Biofuels 2008, I:I2.

40. Trinh CT. Unrean P, Srienc F: Minimal Escherichia coli cell for the most efficient production of ethanol from hexoses and pentoses. Appl Environ Microbiol 2008, 74:3634-3643.

4l. Causey TB, Zhou S, Shanmugam KT, Ingram LO: Engineering the metabolism of Escherichia coli W3 110 for the conversion of sugar to redox-neutral and oxidized products: Hombacetate production.. Proc Natl Acad Sci U S A 2003, 100:825-832.

42. Sa inchez AM, Bennet GN, San KY: Effect of different levels of NADH availability an metabolic fluxes of Escherichia ooli chemostat cultures in defined medium. J Biotechnol 2005, 117:395-405.

43. dos Santos MM, Raghevendran V, Kotter P, Olsson L, Nielsen J: Manipulation of malic enzyme in Saccharomyces cerevisiae for increasing NADPH production capacity aerobically in different cellular compartments. Metab Eng 2004, 6:352-363.

44. Sanchez AM, Andrews J, Hussein I, Bennett GN, San KY: Effoct of overexpression of a soluble pyridine nucleotide transhydrogenase (UdhA) on the production of poly(3-hydroxybutyrate) in Escherichia colit. Biotechnol Prog 2006, 22:420-425.

45. Tishkov VI, Popoy VO: Protein engineering of formate dehydrogenase. Blomol Eng 2006, 
$\mid$ 
23:89-1 10.

46. Bro C, Regenberg B, Forster J, Nielsen I; In silico aided metabolic engineering of Saccbaromyces cerevisiae for improved bioethanol production. Metab Eng 2006, 8:102-1 11.

47. Andrianantoandro E, Basuz S, Karig DK, Wejss R: Synthetic biology: new engineeríng rules for an eminging discipline. Mol Syst Biol 2006, 2:2006.0028.

48. Pfleger BF, Pitera DJ, Smolke CD, Keasling JD: Combinatorial enginetring of intergenic regions in operens tunes expression of multiple genes. Nat Biotechnol 2006, 24:1027-1032.

49. Li MZ, Elledge Sl: Harnessing homologous recombination in vitro to generate recombinant DNA via SLJC. Nat Methods 2007, 4:251-256.

50. Vroom JA, Wang CL: Modular construction of plasmids though ligation-free assembly of vector components with oligonucleotide linkers. Biotechniques 2008, 44:924-926.

51. Shetty RP, Endy D Jr, Knight TF: Engineering BioBrick vectors from BioBrick parts. J Biol Eng $2008,2: 5$.

52. Win MN, Smolke CD: A modular and extensible RNA-based gene-regulatory platform fọr engimeering cellular function. Proc Natl Acad \$ci U S A 2007, 104:14283-14288.

53. Lee SK, Chou HH, Pfleger BF, Newman JD, Yoshikuni Y, Keasling JD: Directed evolution of AuaC for improved compatibility of arabinos and lactose-inducible promaters. Appl Environ Microbiol 2007, 73:5711-5715.

54. Dueber JE, Mirsky EA, Lim WA: Engineering synthetic signaling proteins with ultrasensitive inputoutput control. Nat Biotechnol 2007, 25:660-662.

55. Anderson JC, Voigt CA, Arkin AP: Environmental signal integration by a modular AND gate. Mol Syst Biol 2007, 3:133.

56. Anderson JC, Clarke EJ, Arkin AP, Voigt CA: Environmentally controlled invasion of cancer cells by engineered bactería. J Mol Biol 2006, 355:619-627.

57. Brenner K, Karig DK, Woiss R, Arnold FH: Engineered bidirectional communiction mediates a consensus in a microbial biofilm consortium. Proc Natl Acad Scì U S A 2(107, 104:17300-17304.

58. Ro DK. Paradise EM, Ouellet M, Fisher KJ, Newman KL, Nđungu JM, Ho KA, Eachus RA, Ham TS, Ktrby $J$ et al: Production of the antimalarial drug precursor artemisinic acid in engineered yeast. Nature 2006, 440:940-943,

59. Martin VJ, Pitera DJ, Withers ST, Newman JD, Keasling JD: Engineering a mevalonate pathway in Escherichia coli for production of tempenoids. Nat Biotechnol 2003, 21:706-\$02.

60. Chang MC, Keasling JD: Production of isoprenoid pharmaceuticals by engineared microbes. Nat Chem Biol 2006, 2:674-681.

61. Canton B, Labno A, Endy D: Refinement and standardization of s synthetic biological parts and devices. Nat Biotechnol 2008, 26:787-793.

62. Guido NJ, Wang X, Adalsteinsson D, McMillen D, Hasty J, Cantor CR, Elston TC, Collins JJ: A bottom-up approach to gene regulation. Nature 2006, 439:856-B60.

63. Batt G, Yordanov B, Weiss R, Belta C: Robustness analysis and tuning of synthetic gene networks. Bíoinformatics 2007, 23:2415-2422.

64. Gibson DG, Beuders GA, Andrews-Pfannkoch C, Denisova EA, Baden-Tillson H, Zaveri J, Stockwell TB, Brownley A, Thomas DW, Algire MA et al.: Complete chemical synthesis, assembly, and cloning of a Mycoplassma genitalium genome. Science 2008, 319:1215-1220.

This work was supported by the Director, Office of Science, Office of Basic Energy Sciences, of the U.S. Department of Energy.

This work was supported by the Assistant Secretary for Energy Efficiency and Renewable Energy, Office of Building Technology, State, and Community Programs, of the U.S. Department of Energy.

\section{DISCLAIMER}

This document was prepared as an account of work sponsored by the United States Govemment. While this document is believed to contain correct information, beither the United States Govemment nor any agency therefof, not The Regents of the University of Califomia, nor any of their employeds, makes any warranty, express or implied, or assumes any legal responsibility for the accuracy, completeness, or usefutness of any 
information, apparatus, product, or process disclosed, or represents that its use would not infringe privately owned rights. Reference herein to any spexific commercial product, process, or service by ito trade name, trademark, manufacturer, or otherwise, does not necessarily constitute or imply its endorsement, recommendalion, or favoring by the United States Government or any agency thereof, or The Regents of the University of California. The views and opinions of authors expressed herein do not necesstarily state or reflect those of the United States Govemment or any agency thereof or The Regents of the University of Califormia.

\section{CONTRACT NUMBER}

DE-AC02-0SCH11231. 
